\title{
Control of Hazardous Chemical as an Effort for Compliance Criteria of OHS Management System : A Cross-Sectional Study at PT. X Surabaya, Indonesia by Fransisca Anggiyostiana Sirait
}

Submission date: 23-Jul-2020 06:13PM (UTC+0800)

Submission ID: 1361148883

File name: 7.pdf (357.07K)

Word count: 3046

Character count: 15626 


\title{
Control of Hazardous Chemical as an Effort for Compliance Criteria of OHS Management System : A Cross-Sectional Study at PT. X Surabaya, Indonesia
}

\author{
Fransisca Anggiyostiana Sirait ${ }^{1}$, Abdul Rohim Tualeka $^{1}$, Indriati Paskarini $^{1}$, Samsul Arifin $^{1}$ \\ ${ }^{I}$ Department of Occupational Health and Safety, School of Public Health, Airlangga University, Indonesia
}

\begin{abstract}
Background: OHS is a condition that must be realized in the workplace with all efforts based on science and deep thinking to protect the workforce, people, work and culture through the application of accident prevention technology that is done consistently in accordance with applicable laws and standards. The purpose of this study was to determined the appropriate control of hazardous chemicals as an effort to fulfill the criteria in the OHS management system in the welding workshop at PT. X Surabaya, Indonesia.
\end{abstract}

Method: The research method was cross sectional study. Primary data obtained from the observation with the review of compliance criteria in OHSMS and direct interviews to HSE officer. Secondary data was obtained from corporate documents, including company policies, commitments and Standard Operating Procedures. Data analysis was completed with presentation in the form of tables and explanations.

Result: The results showed that on the principle of monitoring and performance evaluation there are $3^{\text {rd }}$ element with 46 criteria are fulfilled and 1 criterion was not fulfilled the category of minor findings, namely criteria 9.3 .5 , and the calculation of achievement level was $97,87 \%$.

Conclusion: The conclusion of this study was that the control of hazardous chemicals in the company still not fulfilled the criteria in OHS management system, while the appraisal rate was in satisfactory category.

Keywords: Hazardous Chemical, OHS Management System, OHS Performance, Risk Management.

\section{INTRODUCTION}

The rapid advancement of technology boosts every sector of the industries to use the modern technology in doing any of their job. The competition of the industry that becomes more competitive demands every company to optimize the whole resource they have, some of them are financial, physical, human, and technology. Human as the resource becomes one of the keys from the success of a development. One of the way to boost the

\section{Corresponding author :}

\section{Abdul Rohim Tualeka}

Lecturer in Occupational Health and Safety

Department, Public Health Faculty, Airlangga

University, Surabaya, 60115, Indonesia

Tel: +62 $315920948 /+6281333519732$

Fax: +62 31 5924618E-mail: inzut.tualeka@gmail.com quality of the human resources is by guaranteeing the Occupational Health and Safety (OHS) of every worker, whether for the worker with the lowest risk of work up to those who needs a lot of concentration and great deal of physical power.

The data of International Labor Organization (ILO) mentioned that at 2010 is noted that in each year, more than 2 million people died for the work accident and disease caused by the workplace, and it happened that about 270 million of work accident per year in the world $^{[6]}$. In Indonesia, the number of work accident indicates a worrying outcome. This thing is based on the result of research of ILO that Indonesia get the $52^{\text {nd }}$ spot from $53^{\text {rd }}$ in how lacking the management of OHS. The cost that will be spent by the company will be massive, if there is any accident in workplace. 
The theory of Domino according to H.W. Heinrich that the cause of work accident, $88 \%$ of it is due to unsafe action, $10 \%$ of it is because of unsafe condition and $2 \%$ of it is unavoidable occurrence ${ }^{[2]}$. One of the attempt to reduce the unsafe action and the unsafe condition is by doing the risk management. The risk management of OHS related to the danger and the risk that exist in the workplace that can cause loss by the company. If this thing happened beyond control, then it can threaten the continuity of the business or the development process ${ }^{[6]}$.

OHS stands for Occupational Health and Safety, abbreviated as OHS. OHS is a condition that must be realized in the workplace with all efforts based on science and deep thinking to protect the workforce, people, work and culture through the application of accident prevention technology that is done consistently in accordance with applicable laws and standards. Safety is the safety associated with machinery, tools, materials and processing, platform and environment ${ }^{[8]}$.

The Law Number 1 of 1970 about The Work Safety mentioned that every worker has the rights on protection upon the safety in doing the work for the prosperity and increasing production, as well as the national productivity ${ }^{[9]}$. Based on that, then the company must guarantee the safety and health of the workers when working and when is located in the workplace. While, the Article Number 87 of Law Number 13 year 2003 about The Employment mentioned that every company must apply the occupational health and safety management system (OHSMS) that is integrated with the management system of the company ${ }^{[10]}$.

OHS management system guided by the applicable regulation in Indonesia. Based on Article Number 5 Government Regulation or Peraturan Pemerintah (PP) of Republic Indonesia Number 50 of 2012 about the Application of OHSMS mentioned that every company must apply the OHS management system in its company [5]. The application of OHSMS in companies has the aim to increase the effectiveness of the protection of OHS, as well as the comfort and efficient in pushing the productivity. The number of work accident happened is big enough on the company that can not apply the OHS management system, while the company that has already apply the OHSMS is proven to experience a reduction in the number of work accident.

The result of risk scoring in working process in PT. $\mathrm{X}$ Surabaya, Indonesia, that generally the danger is in the category of risk in the level of II, III, and IV. For example, the working in height, operational of forklift, install/dismantling scaffolding, cutting, welding, and grinding. On the process of welding, there is the use of chemical that is acethylene and lubricant oil.

PT. X has applied OHS management system integrated with the management system of this company. The application of OHS management system was done in every process of the work, while monitored by the division named OHS and environment (OHS\&E). HSE of PT. X has socialized the programs of OHS\&E to all of the workers. There was the HSE plan that functions to increase work and the commitment of application management system in the company, as well as there is the practice of internal audit from that division, as well as the external audit. Therefore, the further research was needed about the control of hazardous chemicals as the attempt to fulfill the criteria based on the Government Regulation of Republic Indonesia Number 50 of 2012 [5]. While the purpose from the practice of this research is to find out the correct control of hazardous chemicals as the attempt to fulfill the criteria in OHSMS.

\section{MATERIAL AND METHOD}

The location for this research was in the workshop of the welding of PT. X Surabaya, Indonesia. The time of this research was on February until March of 2017. The method used the descriptive study. This was intended because the result will give the clear and correct picture about the control of the hazardous chemicals as the attempt of fulfilling the criteria of OHS management system based on the Government Regulation of Republic Indonesia Number 50 of $2012^{[5]}$.

The primary data in this research was gained from the result of the observation and interview directly. The data obtained by doing some review on the practice of monitoring and evaluation of the work of OHS in company and based on the document related that occur in the workshop of welding of PT. X, as well as adjusted with the condition on site or in workplace. Observation done by using the checklist sheets of criteria upon the application of OHSMS based on Government Regulation of Republic Indonesia Number 50 of $2012^{[5]}$. The direct interview done by using the instrument in the form of structured guideline of interview that composed based on the Attachment II of this Government Regulation that was to the HSE officer. The secondary data obtained 
from the archive documented by this company, such as the organization structure, company policy and commitment of the leader, Standard Operating Procedure (SOP), company management system, and the related documents.

\section{FINDINGS/RESULTS}

The elements found in the principles of monitoring and evaluation of work of OHS were the monitoring standard; reporting and repairing of lacks; material processing and its mobility; the data collection and usage; as well as the checking or audit of the OHS management system. The fulfilling criteria that occurs inside each of the elements on the practice of monitoring and evaluation for the work of OHS at PT. X Surabaya, Indonesia, presented in Table 1 below.

Table 1. Result of Fulfilment of Criteria in the Practice of Monitoring and Evaluation for the Work of OHS in PT. X Surabaya, Indonesia, 2017

\begin{tabular}{|c|c|c|c|c|}
\hline \multirow[b]{2}{*}{ No. } & \multirow[b]{2}{*}{ Element } & \multirow[b]{2}{*}{ Sub-Element } & \multicolumn{2}{|l|}{ Criteria } \\
\hline & & & Fulfilled & $\begin{array}{l}\text { Not Fulfilled } \\
\text { (Minor) }\end{array}$ \\
\hline & \multirow{4}{*}{ Monitoring Standards } & 7.1 Checking for danger & 7 criteria & - \\
\hline & & 7.2 Monitoring/measuring the workplace & 3 criteria & - \\
\hline & & $\begin{array}{l}\text { 7.3 Tools Checking/Inspection, } \\
\text { measuring and testing }\end{array}$ & 2 criteria & - \\
\hline & & $\begin{array}{l}\text { 7.4 Monitoring upon the health of } \\
\text { Employee }\end{array}$ & 5 criteria & - \\
\hline & \multirow{4}{*}{$\begin{array}{l}\text { Reporting and } \\
\text { repairing for the lacks }\end{array}$} & 8.1 Reporting of danger & 1 criteria & - \\
\hline & & 8.2 Reporting of accident & 1 criteria & - \\
\hline & & 8.3 Checking and study of accident & 6 criteria & - \\
\hline & & 8.4 Handling of problem & 1 criteria & - \\
\hline & \multirow{3}{*}{$\begin{array}{l}\text { Material management } \\
\text { and displacement }\end{array}$} & 9.1 Handling manually and mechanically & 4 criteria & - \\
\hline & & 9.2 Transporting system, storage and disposal & 3 criteria & - \\
\hline & & 9.3 Controlling upon the hazardous chemicals & 4 criteria & 1 criteria \\
\hline & \multirow{2}{*}{$\begin{array}{l}\text { Data collection and } \\
\text { usage }\end{array}$} & 10.1 Note of OHS & 4 criteria & - \\
\hline & & 10.2 Data and Report of OHS & 2 criteria & - \\
\hline & Checking of SMK3 & 11.1 Internal audit & 3 criteria & \\
\hline \multicolumn{3}{|c|}{ Total } & 46 criteria & 1 criteria \\
\hline
\end{tabular}

Based on Table 1 above, it can be found out that from 47 criteria of scoring in practice of monitoring and evaluating the work of OHS PT. X has fulfilled 46 criteria and 1 criteria has not fulfilled with the minor category, that was in the criteria number 9.3.5. The data of the result upon the study indicated that from the five elements in the principles of monitoring and evaluating the work of OHS, there were 46 criteria that is fulfilled and 1 criteria that was not fulfilled (minor category). Then the calculation upon the level of achievement for the practice of monitoring and the evaluating the work of OHS at PT. X was as follows:

\begin{tabular}{|c|}
46 criteria fulfilled \\
47 criteria
\end{tabular} $100 \%=\mathbf{9 7 , 8 7 \%}$


Based on the calculation above, then the score achieved in the practice of monitoring and evaluating the work of OHS is $97,87 \%$. Therefore, PT. X was in the classification of "Satisfactory" in term applying the criteria.

\section{DISCUSSION}

The monitoring and the evaluating the works of OHS is the requirement in applying the OHSMS that can be used to ensure the practice of OHS in the company works properly and according to the planning. Ramli argued that the principle of monitoring and evaluation of OHS can be used to find out if there is any unwanted violation so that later can be repaired immediately ${ }^{[6]}$. In the principle of monitoring and evaluating the work of OHS, there are 5 elements with 14 sub-elements, and the total criteria are 47 points.

PT. X has the total employees of more than 200 persons and there are some jobs with relatively high risk of practice so that the scoring upon the practice OHSMS is needed by scoring the monitoring and the evaluation of the work of OHS in every activity and working program that is used. Based on the result of interview with the HSE officer, it was found out that the HSE has done the monitoring upon the practice of all program of OHS\&E regularly in every month.

Bird and Germain in the theory of Loss Caution Model focuses on the importance of the role of to prevent and controlling the accidents, that possibly seen as uncontrollable in a complex situation by using the advancing technology ${ }^{[1]}$. This theory is more prioritizing the direct relationship between the management with the cause and effect from the accident and the multilinear interaction from the order of factors of cause and effect. This theory also explained that the failure in control also influences the occurrence of work accident, including inside is the lack of strength upon the policy and standard of working program. If the policy, rules, and standard do not working well, then unsafe action and unsafe condition might still happen frequently.

The identification of unsafe action and unsafe condition was done through the Hazard Observation (HO), safety patrol, and inspection. The checking or inspection upon the working place and the way employees work was done by the competent safety officer that was properly assigned to and was able to identify danger. This action was done regularly at least monthly.
There was a schedule and procedure of operation for the inspection, including the 5R, HO, and JHA. PT. X has kept records of expiration and safe placement as a requirement in the fulfillment of OHSMS on criteria about the control of damaged or expired materials Besides, there also the document of Material Safety Data Sheets that discuss about the safety of materials and how to handle it according to the rules of the constitution, as well as supplemented with clearly tagged label on the hazardous chemicals.

The criteria 9.3.5 in the fulfilling of implementation of SMK3 based on the Government Regulation of Republic Indonesia Number 50 of $2012^{[5]}$ that is included in the element of material processing and its mobility, stated that the handle of hazardous chemicals is done by the competent and authorized officer. The handling of the hazardous chemicals in PT. X has done by the competent officer who is a graduate from the chemistry study program. However, this officer has not yet acquire the license or the certificate of expertise for example the certificate of expert chemist so that in this case was a minor category finding in that certain criteria.

The scoring category for the fulfillment of the implementation of SMK3 based on the Government Regulation of Republic Indonesia Number 50 of $2012^{[5]}$. In which the level of achievement of $0-59 \%$ is classified in the achievement of "Lacking", the score of $60-84 \%$ is classified as "Good", and the score of $85-100 \%$ is classified as "Satisfactory".

Based on the result of the study, it can be concluded that the score of OHS implementation is $97.87 \%$, it means that the PT. X has implement SMK3 in the level of "Satisfactory". One of the goal of implementing OHSMS based on the Government Regulation of Republic Indonesia Number 50 of 2012 is to prevent and reduce the number of work accident as well as the sickness due to the work ${ }^{[5]}$. The consistent implementation of SMK3 can be useful as the protection for the workers. PT. X has applied management system of occupational safety and health to achieve zero accident. However, it is undeniable that there are still some danger potential and risks in each processes of work or production.

\section{CONCLUSION}

Based on the result of the study, then the following conclusions can be drawn: 
The minor finding in the scoring of the practice of monitoring and evaluating the work of OHS is in the criteria 9.3.5, that is the welding workshop of PT. X has acquired the procedure of storage, handling, and the mobility of hazardous chemical, as well the marking system or the tag labelling done by the authorized officers that is competent with the chemistry educational background, yet the officer has not acquired any special certificate (expert of OHS in chemistry).

Based of the calculation upon the level of achievement of the practice of monitoring and evaluating the work of OHS that PT. X was in the category of "Satisfactory".

\section{RECOMENDATION}

Assign or point one or more officers in handling the hazardous chemicals and giving the training upon the danger and the way to handle or control that, as well as planning the certification program for the specific skill that is suitable that is the OHS experts in chemistry and the OHS of chemistry officers based on the Decree of the Minister of Employment of Republic Indonesia Number Kep.187/MEN.1999 ${ }^{[4]}$ about the control of hazardous chemicals in workplace. This is related to the use of acethylene in the welding working process and the lubricant oil used in the workshop.

Conflict of Interest: All authors have no conflicts of interest to declare.

Source of Funding: This is an article "Control of Hazardous Chemical As An Effort For Compliance Criteria of OHS Management System: A Cross-Sectional Study at PT. X Surabaya, Indonesia" that was supported by School of Public Health, Airlangga University, Indonesia, 2017.

Ethical Clearance: Taken from Public Health Faculty Committee of Airlangga University, Indonesia.

\section{REFERENCES}

1. Bird Jr., E. Frank dan Germain L. George. 1992. Practical Loss Control Leadership. Atlanta: International Loss Control Institute, Inc.

2. Heinrich, H.W. 1980. Industrial Accident Prevention. New York: Mc. Graw Hill Book Company.

3. Fausiyah, K. 2012. Penerapan Sistem Manajemen K3 (SMK3) dan Gambaran Unsafe Action Selama Tahun 2011 di PT Kertas Leces (PERSERO) Probolinggo. Surabaya: Fakultas Kesehatan Masyarakat Universitas Airlangga.

4. Menteri Tenaga Kerja Republik Indonesia. 1999. Keputusan Menteri Tenaga Kerja Republik Indonesia Nomor Kep.187/Men/1999 Tentang Pengendalian Bahan Kimia Berbahaya Di Tempat Kerja. Jakarta.

5. Presiden Republik Indonesia. 2012. Peraturan Pemerintah Republik Indonesia Nomor 50 Tahun 2012 Tentang Penerapan Sistem Manajemen Keselamatan dan Kesehatan Kerja. Jakarta.

6. Ramli, S. 2010. Manajemen Resiko Keselamatan dan Kesehatan Kerja. Dian Rakyat. Jakarta.

7. Ramli, S. 2013. Smart Safety Panduan Penerapan SMK3 yang Efektif. Dian Rakyat. Jakarta.

8. Tarwaka. 2008. Keselamatan dan Kesehatan Kerja "Manajemen dan Implementasi K3 di Tempat Kerja”. Harapan Press. Surakarta.

9. Presiden Republik Indonesia. 1970. Undang Undang Nomor 1 Tahun 1970 Tentang Keselamatan Kerja. Jakarta.

10. Presiden Republik Indonesia. 2003. Undang Undang Nomor 13 Tahun 2003 Tentang Ketenagakerjaan. Jakarta. 
Control of Hazardous Chemical as an Effort for Compliance Criteria of OHS Management System : A Cross-Sectional Study at PT. X Surabaya, Indonesia

ORIGINALITY REPORT

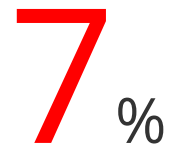

SIMILARITY INDEX

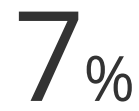

INTERNET SOURCES
$4 \%$

PUBLICATIONS
$5 \%$

STUDENT PAPERS

PRIMARY SOURCES

1 Submitted to Universitas Airlangga

Student Paper

2 www.indianjournals.com

3 ijrat.org

Internet Source

4 repository.ubaya.ac.id Internet Source

5 worldwidescience.org

6 WwW.ijrat.org 
Control of Hazardous Chemical as an Effort for Compliance Criteria of OHS Management System : A Cross-Sectional Study at PT. X Surabaya, Indonesia

GRADEMARK REPORT

FINAL GRADE

10

PAGE 1

PAGE 2

PAGE 3

PAGE 4

PAGE 5
GENERAL COMMENTS

Instructor 